\title{
THE INFLUENCE OF VIBRATION EXERCISES ON THE PSYCHOPHYSIOLOGICAL QUALITIES OF ATHLETES
}

\author{
Alexander Mikheev, Natalia Paramonova \\ Scientific Research Institute of Physical Culture and Sport of Republic of Belarus, Minsk, Belarus
}

\begin{abstract}
Alexander Mikheev. Dr. Habil. in Biomedical Sciences. Vice director of the Scientific Research Institute of Physical Culture and Sport of Republic of Belarus. Research interests - influence of vibration exercises on the psychophysiological qualities in athletes.
\end{abstract}

\begin{abstract}
The purpose of the research was the study of the effect of dosed vibration training (DVT) on the dynamics of psychophysiological qualities of athletes. The objectives of the research consisted of the determination of the effects of the vibration load on the dynamics of the development of the psychomotor (high-speed, coordination) qualities of athletes. In this study 10 male athletes took part. The average age of the group of test subjects was $13.90 \pm 0.18$ years old, the average body mass $55.61 \pm 3.12 \mathrm{~kg}$, the average body height $171.50 \pm 7.91 \mathrm{~cm}$, the average muscle tissue mass $38.90 \pm 2.85 \%$, the average fat tissue mass $16.40 \pm 2.17 \%$, the average period of participation in sports $4.25 \pm 0.5$ years. Over the course of two training microcycles (14 days) in the period of general training of the yearly training macrocycle athletes performed the program of DVT, which consisted of 8 stimulation training sessions, with 4 training sessions in each of the two weekly microcycles. The vibration load was created by means of the performance of repeated physical exercises with the extremities resting on the vibration devices (platforms), working at the frequency of $28 \mathrm{~Hz}$ and amplitude of $4 \mathrm{~mm}$. With the goal of creating conditions for the global effect of vibrations on the body integrated exercise was proposed to the test subjects covering the greatest mass of working muscles with the vibration effect. The exercise consisted of two parts, performed without a break: arm-pumping exercises from the initial position "sitting back with arms resting on the vibration platforms" and squats on the vibrating platforms. Each parts of the exercise was performed by every trainee until fatigue. In accordance with the program the vibration load increased from training to training due to the addition of one set to the number of sets performed in each preceding series of exercises. In the first exercise the average time of the vibration load was $172 \pm 12$ seconds with an average total number of motion cycles of $169 \pm 10$, and in the last exercise $908 \pm 30$ seconds with an average total number of motion cycles of $698 \pm 31$.

On the basis of the results of the research it can be concluded that vibration training consisting of 8 stimulation series, equally distributed over the course of two microcycles, renders a positive influence on the psychophysiological qualities of athletes. Valid ( $p<0.05)$ improvement in speed of complex motor response $(12 \%)$ was observed immediately after the end of the training series. The precision of the complex choice reaction improved by $56 \%$ in comparison with the original value and maximum tempo of motions within one month improved by $10 \%$. So dozed vibrating training influences psychophysiological qualities effectively and can be recommended for the introduction in the training process of elite athletes.
\end{abstract}

Keywords: Dozed vibrating training (DVT), dozed vibration exercises (DVE), psychophysiological qualities, training microcycle, psychomotor reaction.

\section{INTRODUCTION}

I n sports the question of perfection of a system of training for athletes has always stood out extraordinarily sharply. One of the most important problems is the optimization of the management of the training process, proposing manipulation by available training means and methods, directed at the change in the athlete's condition, first and foremost physical. Qualified athletes, as a rule, possess a high level of special

physical conditions, which can only be raised by intensive and volumetric training suitable to cause the necessary morphological and functional rebuilding. During the preparation of athletes it is very important to create and implement such pedagogical, medical-biological and technical developments that would ensure the steady growth of sports results. Such technologies should be effective, multi-functional and simple at the same 
time. The logic of the development of the problem lead to the idea to use some alternative training methods such as vibrating miostimulation (Bosco et al., 1999; Cardinale, Bosco, 2003) or, as we interpret it, "the dozed vibration training” - DVT (Михеев, 1999; Михеев, 2007). This is an easily reproducible, non-invasive, non-medical method, proposing the performance of physical exercises against the background of vibration with a frequency of $28-30 \mathrm{HZ}$ with an amplitude of $4 \mathrm{~mm}$ - so called dozed vibrating exercises or DVE (Mikheev 1993, Mikheev, 2005). Information on the effectiveness of other frequency and amplitude ranges for growth of sports results is dissimilar and sparse. It should be stated that at the present time the quantity and quality of knowledge on the character of functional changes, which occurred in sportsmen's functions during vibration training, does not answer the growing demands of sports. That is why the purpose of the proposed research was the study of the effect of dosed vibration exercises (DVE) on the dynamics of psychophysiological qualities of athletes. The objectives of the research consisted of the determination of the effects of the vibration load on the dynamics of the development of the psychomotor (high-speed, coordination) qualities of athletes.

\section{METHODS}

In this study 10 male athletes took part. The average age of the group of test subjects was $13.90 \pm 0.18$ years old, the average body mass $55.61 \pm 3.12 \mathrm{~kg}$, the average body height $171.50 \pm 7.91 \mathrm{~cm}$, the average muscle tissue mass $38.90 \pm 2.85 \%$, the average fat tissue mass $16.40 \pm 2.17 \%$, the average period of participation in sports $4.25 \pm 0.5$ years. Over the course of two training microcycles (14 days) in the pe- riod of general training of the yearly training macrocycle athletes performed the program of DVT, which consisted of 8 stimulation training sessions, with 4 training sessions in each of the two weekly microcycles. The vibration load was created by means of the performance of repeated physical exercises with the extremities resting on the vibration devices (platforms), working at a frequency of $28 \mathrm{~Hz}$ and amplitude of $4 \mathrm{~mm}$. With the goal of creating conditions for the global effect of vibrations on the body integrated exercise was proposed to the test subjects covering the greatest mass of working muscles with the vibration effect. The exercise consisted of two parts, performed without a break: arm-pumping exercises from the initial position "sitting back with arms resting on the vibration platforms" and squats on the vibrating platforms. Each part of the exercise was performed by every trainee until coming fatigue. In accordance with the program the vibration load increased from training to training due to the addition of one set to the number of sets performed in each preceding series of exercises (Table 1 ).

In the first exercise the average time of the vibration load was $172 \pm 12$ seconds with an average total number of motion cycles of $169 \pm 10$, and in the last exercise $908 \pm 30$ seconds with an average total number of motion cycles of $698 \pm 31$. For the evaluation of the psychophysiological qualities of athletes the portable psychophysiological diagnostic complex ПФДК-02 (product of Republic of Belarus) was used. This device allows determining the strength of the nervous system, flexibility of the nervous processes, time of the simple motor response, time of the choice reaction, precision of the evaluation of the micro intervals of time, the precision of the reaction to the moving object (RMO), status of the static and dynamic tremor.
Table 1. The protocol of adjacent training sessions with increasing vibrating loadings (rest intervals $3-5 \mathrm{~min}$ )

\begin{tabular}{|c|c|c|c|}
\hline $\begin{array}{c}\text { № } \\
\text { of training } \\
\text { session }\end{array}$ & $\begin{array}{c}\text { Number } \\
\text { of sets in every } \\
\text { training session }\end{array}$ & $\begin{array}{c}\text { Total average duration } \\
\text { of vibrating load, } \\
\mathbf{s}(\overline{\mathrm{X}} \pm \mathrm{S} \overline{\mathrm{X}})\end{array}$ & $\begin{array}{c}\text { Total average } \\
\text { number of motion cycles } \\
(\overline{\mathrm{X}} \pm \mathrm{S} \overline{\mathrm{X}})\end{array}$ \\
\hline 1 & 1 & $172 \pm 12$ & $91 \pm 10$ \\
\hline 2 & 2 & $335 \pm 17$ & $200 \pm 15$ \\
\hline 3 & 3 & $457 \pm 21$ & $318 \pm 19$ \\
\hline 4 & 4 & $579 \pm 28$ & $399 \pm 29$ \\
\hline 5 & 5 & $685 \pm 26$ & $450 \pm 25$ \\
\hline 6 & 6 & $822 \pm 31$ & $561 \pm 30$ \\
\hline 7 & 7 & $908 \pm 32$ & $642 \pm 33$ \\
\hline 8 & 8 & $908 \pm 30$ & $698 \pm 31$ \\
\hline
\end{tabular}




\section{RESULTS}

On the basis of the results of the research it can be concluded that vibration training consisting of 8 stimulation training sessions with increasing vibrating loading, equally distributed over the course of two week's training microcycles, renders a positive influence on the psychophysiological qualities of athletes. Indicators of speed of the simple motor response increased by $4.6 \%$ after the experiment and held this level within 1 month after completion of the program of dosed vibration training. Dynamics of other psychophysiological qualities of athletes had a tendency of improvement as well. So, valid $(p<0.05)$ improvement in speed of complex motor response $(12 \%)$ was observed immediately after the end of experimental vibrating training series. The precision of the complex choice reaction improved by $56 \%$ in comparison with the original value. Maximum tempo of motions within one month improved by $10 \%$.

\section{DISCUSSION}

Strength of the nervous system, flexibility, equilibrium, instability of the nervous processes are typical characteristics of the nervous system,
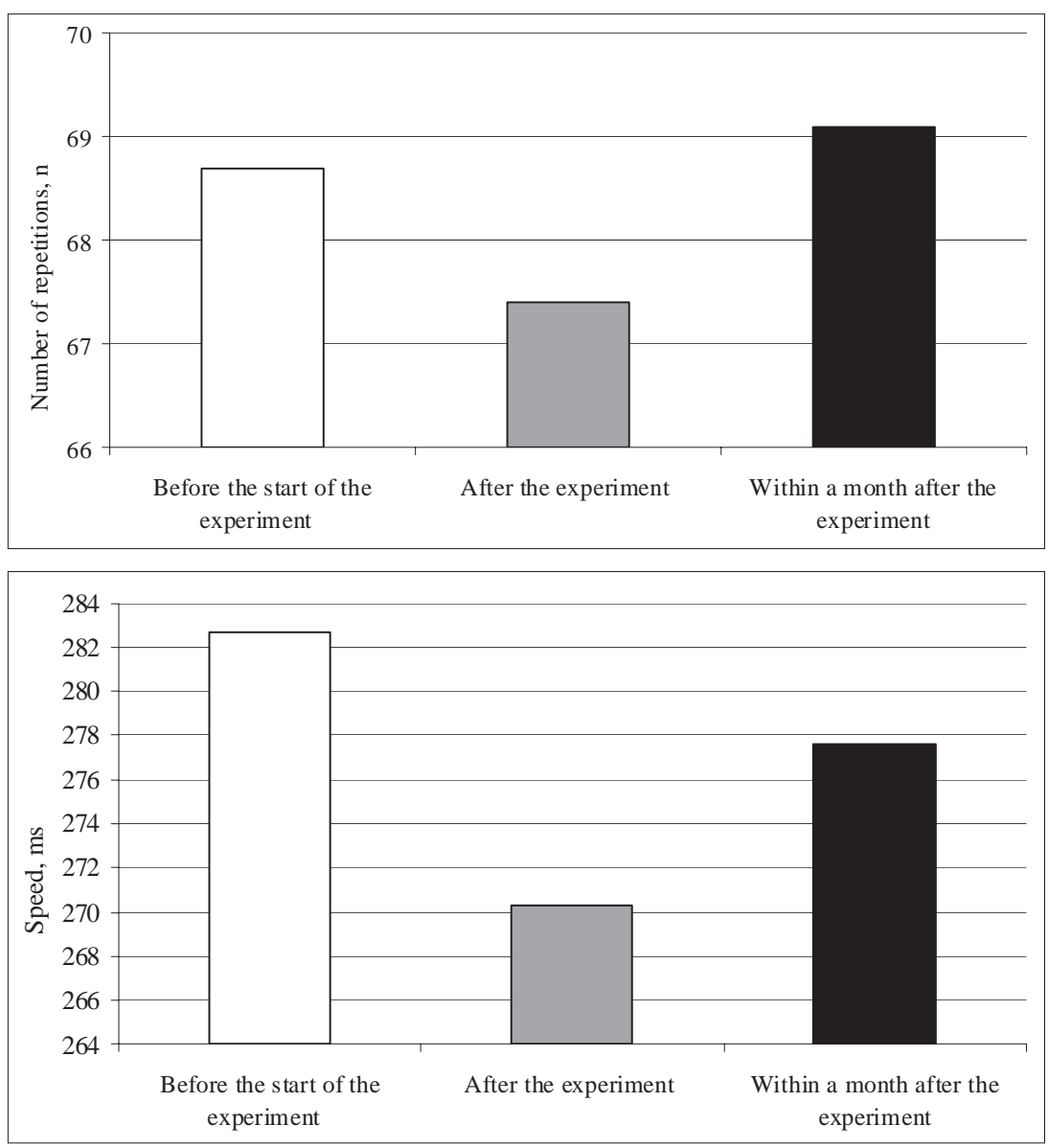

which are the basis of temperament. These qualities are stable and are the "foundation" for the formation of psychomotor qualities.

The psychomotor qualities characterize the precision, intensity and effectiveness of the control of motions in space and time. They are the basis for the perfection of sports technique and significantly determine development of sports skill. Psychomotor qualities include such indicators as the sense of time, time of reaction on a moving object, the maximum tempo of motions, the speed of simple and complex motor reaction, the precision of a complex reaction, the static tremor, the dynamic tremor and others. (Бойко, 1961; Ильин, 1972; Марищук, 1984 a; Марищук, 1984 b).

Results of the research on psychophysiological qualities of athletes are presented in Figures $1-5$. On the diagram (Figure 1) we depicted the dynamics of the maximum tempo of motions (number of repetitions) in graphical form, which unreliably $(p>0.05)$ decreased after stimulation $(67.40 \pm 1.59)$ compared to the initial level $(68.70 \pm 1.99)$. Within one month an improvement was observed in this quality $(p>0.05)$ on average by $10 \%(69.10 \pm 2.20)$ compared to the initial values.

Figure 1. Dynamics of indicators of the maximum tempo of motions (number of repetitions, n) before, after experiment and within 1 month after completion of the program of dosed vibration training

Figure 2. Dynamics of indicators of speed of the simple motor response (ms) before, after experiment and within 1 month after completion of the program of dosed vibration training 
Figure 3. Dynamics of the indicators of speed of the complex motor response (ms) before, after experiment and within 1 month after completion of the program of dosed vibration training
Figure 4. Dynamics of indicators of the precision of complex response (number of errors, $n$ ) before, after experiment and within 1 month after completion of the program of dosed vibration training
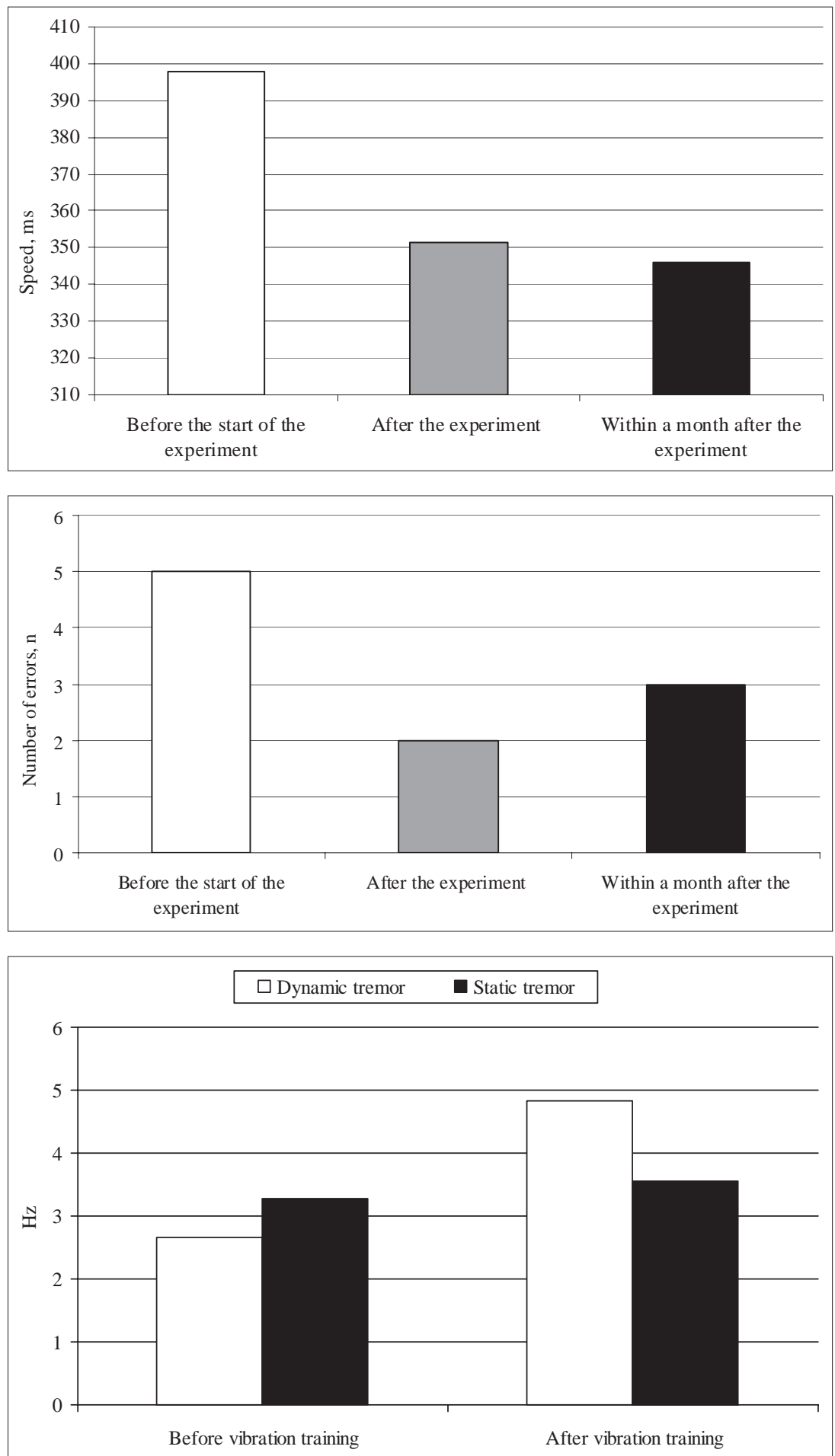

Figure 5. Dynamics of the indicators of static and dynamic tremors $(\mathrm{Hz})$ before, after experiment and within 1 month after completion of the program of dosed vibration training (DVT)
The diagram of the dynamics of the speed of the simple motor response during use of dosed vibration training is presented in Figure 2. After completion of a series of stimulations valid $(\mathrm{p}<0.05)$ improvement in indicators was noted - decrease in time from $282.67 \pm 6.79 \mathrm{~ms}$ to $270.26 \pm 4.59 \mathrm{~ms}(5 \%)$. The results of testing performed within 4 weeks showed that the tendency in the dynamics of the studied quality changed - the indicators of speed of the simple motor response worsened (increased to $277.66 \pm 8.47 \mathrm{~ms}$ ), however it was by $2 \%$ better than the original values.

Results of testing attest to the fact that the dynamics of the speed of complex motor response had a tendency to reliable improvement (Figure $3)$. Valid $(\mathrm{p}<0.05)$ improvement in indicators $(12 \%)$ was observed immediately after the end of the training series (decrease in reaction time from $397.83 \pm 22.97 \mathrm{~ms}$ to $351.46 \pm 12.38 \mathrm{~ms}$ ). After one month this indicator still improved and com- 
prised $345.91 \pm 4.13 \mathrm{~ms}$, that was $13.1 \%$ better than the initial level $(p<0.05)$.

The precision of the complex choice reaction (Figure 4) which characterizes the level of precision of a choice depending on the concrete tactical situation after series of stimulations reliably improved - the margin of error ( $2.2 \pm 0.5)$ decreased by $56 \%$ in comparison with the original value (5.1 \pm 0.8$)$. During the course of the third testing it was clarified that within one month after the end of the program of DVT this indicator remained practically at the achieved level (2.8 \pm 0.3$)$.

From the data set forth in the Figure 5 it follows that indicators of the static tremor increased from $2.66 \pm 1.02$ to $4.84 \pm 1.31$ ( $p>0.05)$ after the end of series of vibration training. Indicators of the dynamic tremor had the same, although a less expressed tendency $(3.27 \pm 0.22$ and $3.56 \pm 0.21)$. It is known that the tremor is connected with a time delay of the correcting afferent impulse, occurring uninterrupted in the effector motor centers during the course of movement and holding a pose in a static position, in connection with which the effector impulses slightly deviate from the necessary amount at this moment and the maintenance of the pose is carried out due to the constant movements relative to some average position.

An increase in the tremor depends on the tonic tension of the muscles and is based on overcoming the processes of stimulation.

\section{CONCLUSION}

On the basis of the results of the research it can be concluded that vibration training consisting of 8 stimulation series, equally distributed over the course of two microcycles, renders a positive influence on the psychophysiological qualities of athletes and can be recommended as a training method for sportsmen of various qualification.

\section{REFERENCES}

Bosco, C., Cardinale, M., Tsarpela, O., Locatelli, E. (1999). New trends in training science: The use of vibrations for enhancing performance. European Journal of Applied Physiology, 79, 306-311.

Cardinale, V., Bosco, C. (2003). The use of vibration as an exercise intervention. Exercise and Sport Sciences Reviews, 31, 1, 3-7.

Mikheev, A. A. (1993). Biological activity stimulation theory and practice. Helping. In Complex Universal Health Improving Program Based on Biological Activity Stimulation of Human Body. Minsk: BCI BelAC UNESCO. P. $17-26$.

Mikheev, A. A. (2005). Effects of dosed longitudinal vibration on athletes. Medicine and Science in Sports and Exercise, 37 (5), 193.

Бойко, Е. И. (1961). Время реакции человека.

Ильин, Е. П. (1972). Сила нервной системы и методы ее исследования. В кн. Психофизиологические основы физического воспитания и спорта. Ленинград. C. $5-15$.
Марищук, В. Л. (1984). Методики психодиагностики в спорте. Москва: Просвещение.

Марищук, В. Л. (1984). Психомоторика спортсмена. Москва: Физкультура и спорт.

Михеев, А. А., Белоусова, Л. В., Волчкова, О. А. (2007). Исследование влияния вибрационных упражнений в сочетании с общей магнитотерапией на психофизиологические качества и психоэмоциональное состояние спортсменов. Научно-практические проблемы спорта высших достижений: материаль междунар. науч. конф. Минск (сс. 179-182).

Михеев, А. А. (1999). Стимуляция биологической активности как метод управления развитием физических качеств спортсменов. Минск.

Михеев, А. А. (2007). Теория вибращионной тренировки (биологическое обоснование дозированного вибротренинга): монография. Минск: БГУФК. 


\title{
VIBRACIJOS PRATIMŲ POVEIKIS SPORTININKŲ PSICHOFIZIOGINE்MS SAVYBËMS
}

\author{
Alexander Mikheev, Natalia Paramonova \\ Baltarusijos kūno kultūros ir sporto moksliniu tyrimu institutas, Minskas, Baltarusija
}

\begin{abstract}
SANTRAUKA
Tyrimo tikslas - ištirti dozuotos vibracijos pratybu poveikį sportininkų psichofiziologinių savybiu kaitai. Taip pat siekta nustatyti vibracijos krūvio poveiki psichomotorinių sportininkų savybių (didelio greičio, koordinacijos) ugdymui.

Buvo tiriama 10 vyrų sportininkų. Jų amžiaus vidurkis $-13,90 \pm 0,18$ m., vidutinè kūno masė — $55,61 \pm 3,12 \mathrm{~kg}$, ūgis $-171,50 \pm 7,91 \mathrm{~cm}$, vidutinè raumenų mase $-38,90 \pm 2,85 \%$, vidutinè riebaus audinio masè $-16,40 \pm 2,17 \%$. Tiriamieji sportavo vidutiniškai 4,25 $\pm 0,5$ metus. Per metini treniruočiu makrociklą sportininkams du mikrociklus (po 14 dienu) buvo taikomas dozuotas vibracijos krūvis, kurị sudarè 8 vibracijos pratybas, po keturias per kiekvieną dvisavaitini mikrociklą. Sportininkai darydavo pratimus laikydami galūnes ant vibruojančiu prietaisų (platformu), kurių vibracijos dažnumas — $28 \mathrm{~Hz}$, amplitudè $4 \mathrm{~mm}$. Norėdami, kad vibruotų visas kūnas, tiriamiesiems skyrėme tokius pratimus, kurių metu dirbtų daugiausia raumenų. Pratimus, kurie buvo atliekami be pertraukos, sudare dvi dalys: atsispaudimai, laikant rankas ant vibruojančios platformos ir pritūpimai stovint ant platformos. Visi pratimai buvo atliekami tol, kol sportininkai pavargdavo. Pagal programos reikalavimus vibracijos krūvio apimtis didėdavo per kiekvienas pratybas. Per pirmas pratybas vibracijos krūvis vidutiniškai truko $172 \pm 12 \mathrm{~s}$ ir buvo atliekama $169 \pm 10$ judesių ciklų, per paskutinę - $908 \pm 30$ s, vidutiniškai atliekant $698 \pm 31$ judesių ciklų.

Aštuonių vibracijos pratybu, ypač jei jos išdesstytos per du mikrociklus, daro teigiamą poveiki sportininku psichofiziologinèms savybèms. Iš karto po treniruočiu padidejjo kompleksiniu motoriniu reakciju greitis $(12 \%, p<0,05)$. Sudètingos pasirenkamosios reakcijos tikslumas pagerèjo 56\%, lyginant su jos reikšme iki pratybu, o maksimalus judesiu tempas per vieną mènesi - 10\%. Taigi dozuotos vibracijos pratybų krūvis teigiamai paveikè psichofiziologines sportininkų savybes, todèl jis rekomenduotinas didelio meistriškumo sportininkų treniruotėms.
\end{abstract}

Raktažodžiai: dozuotos vibracijos pratybos, dozuotos vibracijos pratimai, psichofiziologinès savybès, treniruočiu mikrociklas, psichomotorinè reakcija. 